\title{
Utilization and Medicinal Value of Indigenous Leafy Vegetables Consumed in Urban and Peri-Urban Nairobi
}

By

Judith Kimiywe ${ }^{* 1}$, Judith Waudo ${ }^{1}$, Dorcus Mbithe ${ }^{1}$ and Patrick Maundu ${ }^{2}$

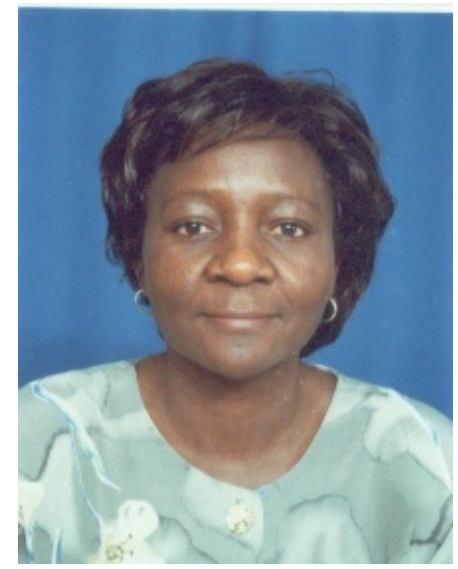

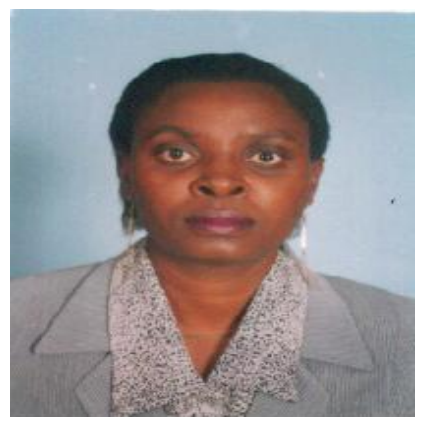

Dorcus Mbithe ${ }^{1}$

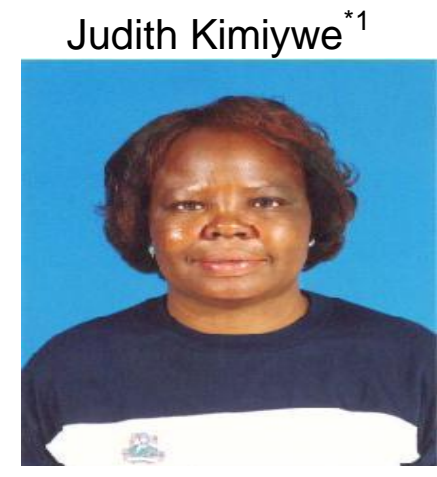

Judith Waudo ${ }^{1}$,

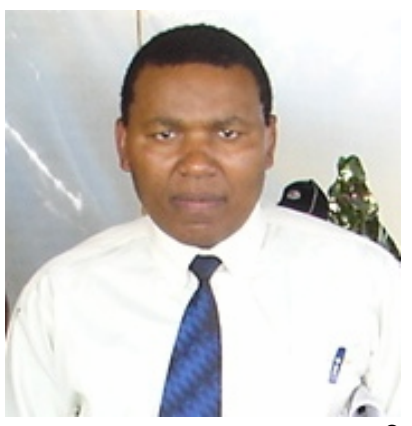

Patrick Maundu ${ }^{2}$

Corresponding author Email: jokimiywe@yahoo.com

${ }^{1}$ Kenyatta University, Department of Foods, Nutrition and Dietetics, P.O Box 43844, Nairobi, Kenya.

2Bioversity International, P.O Box 30677, Nairobi, Kenya. Email: p.maundu@cgiar.org. 


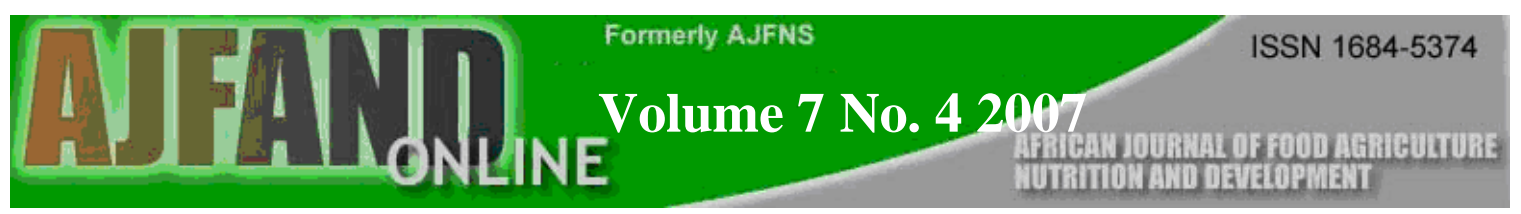

\section{ABSTRACT}

Indigenous African leafy vegetables have recently been attracting research attention not only in terms of their inherent nutrition quality but also the healing power of some of these plants. Diversification of diets through increased utilization and consumption of these vegetables would go along way in alleviating hidden hunger and malnutrition. The main objective of this survey was to determine the consumption patterns and medicinal use of indigenous African leafy vegetables by the residents of urban and peri-urban Nairobi. A descriptive cross-sectional survey was conducted and the survey subjects included populations from all socio-economic strata and income levels. Probability proportional to size stratified sampling was used to select a representative sample of 800 households (600 urban and 200 peri-urban). Data were collected through structured questionnaires, focus group discussions and an observation checklist guide. A picture guide consisting of all foods available on the Nairobi markets was prepared, and used by the researchers to help the respondents to identify the vegetables they consumed. Ethnic origin was found to greatly influence consumption of indigenous African leafy vegetables. There was no significant relationship between household income and education level and choice or use of indigenous leafy vegetables. Some of the reasons for not consuming the vegetables included prohibitive costs and not knowing how to cook them especially those from other tribes. More than 60 percent of the respondents reported that the vegetables had a medicinal value attached to it and some were said to cure more than one disease. About half of those who used them also said the vegetables were healthy. It was concluded that dietary diversity of indigenous African leafy vegetables in addition to providing essential nutrients presumably offers broad benefits to health. The findings support interventions to promote use of indigenous African leafy vegetables as a foodbased initiative towards alleviation of micronutrient deficiencies and poverty through premium value addition incentive strategies.

Key words: Indigenous Leafy Vegetables, nutritional, medicinal 


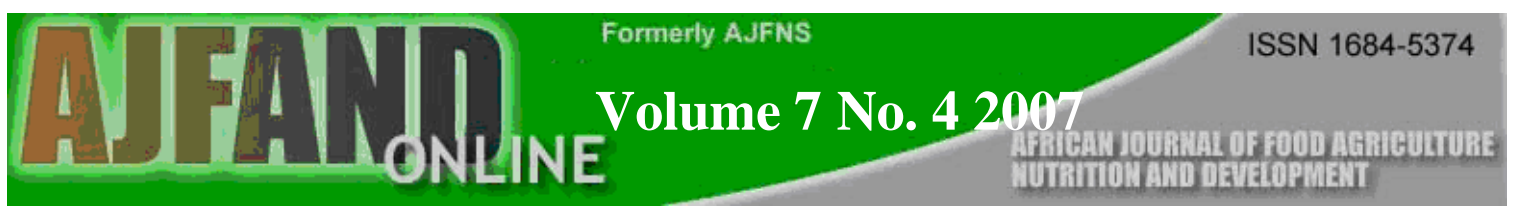

\section{INTRODUCTION}

Nutrition plays a central role in alleviating food insecurity and ill health in developing countries. Studies have also shown the potential synergetic effect of indigenous African leafy vegetables as nutraceuticals (micro-nutrient dense and medicinal) [1]. Kenya is experiencing a decline in the consumption of indigenous African leafy vegetables, the main reason for such a trend being lack of knowledge of the correct choice of foods and hence reduced dietary diversity [2]. Studies have shown that indigenous vegetables apart from their inherent nutritional quality also have healing power $[3,4]$. Considering the difficulty in precisely identifying optimal diets, a diverse and balanced diet, including a variety of indigenous African leafy vegetables provides an intrinsic buffer against the uncertainties of change and remains the preferred choice for human health [5]. Diversification of diets through increased utilization and consumption of indigenous African leafy vegetables was the main focus of the survey. The main objectives of the survey were to establish the food consumption patterns, practices and medicinal use of indigenous African leafy vegetables by the residents of urban and peri-urban Nairobi, Kenya. Ethnicity was found to strongly influence choice and consumption of indigenous African leafy vegetables. This was evident from families with all members originating from one tribe and those households that had members from different tribes. Occupation was also found to strongly influence choice and consumption of indigenous African leafy vegetables. This was brought forth depending on the time one has for buying, preparing and cooking these vegetables. Availability of these vegetables was another main factor of their choice and consumption by the respondents. Generally the respondents reported that the indigenous vegetables they consumed were medicinal. Some vegetables were reported to cure more than one illness. Other studies have also found out that consumption of indigenous vegetables can cure and/or manage diseases [6].

\section{MATERIALS AND METHODS}

A descriptive cross sectional research design was adopted for this survey to cover urban and peri-urban populations in Nairobi. The survey took place between February and May 2005. A total of 32 enumeration areas, 24 of which were in urban and 8 in the peri-urban Nairobi were visited and a sample of 791 households, 592 in urban and 199 in peri-urban interviewed. The urban and periurban households were disproportionately allocated to the two types of areas of survey. This was necessitated by the small size of the peri-urban areas. There were two stages of sample selection in this survey. These were the Primary Sampling Units (PSUs) and the households. The primary sampling unit for the survey was the enumeration areas (EAs) created for the Population and Housing Census of 1999. The allocated EAs were selected independently in the two areas

Published by Rural Outreach Program
KARI-NARL Complex, Westlands, off Walyaki Way
P.O. Box 29086-00625 TEL; +254-20-4444030 FAX: +254-20-4444030
Nairobi, KENYA
Email: oniango@iconnect.co.ke OR info@ajfand.net www.ropkenya.org




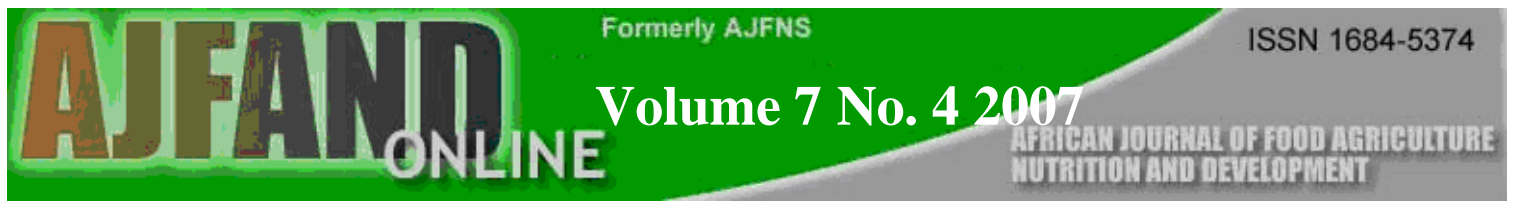

of the survey using the Probability Proportional to Size (PPS) method. The selection of the households was done using the random walk method. The enumeration areas were drawn across the socio-economic classes of the upper, the lower upper, middle, lower middle and lower. This was for purposes of monitoring variations in consumption of indigenous leafy vegetables.

The data collection instruments were pre-tested in February 2005 and they included interview schedules, which were complemented by a picture book [7], Focus Group Discussion guides and an observation checklist guide. The collected data were analyzed both quantitatively and qualitatively using the statistical package for social sciences (SPSS). Descriptive summary statistical were used to describe the demographic profiles of the study population. In addition, descriptive summary statistics were used to establish the commonly consumed indigenous leafy vegetables, frequency of their consumption and their medicinal value. Chi-square tests were used to obtain $p$-values. Analysis of variance (ANOVA) was also used to compare means in consumption among the urban and peri-urban Nairobi residents. A p-value of $\leq 0.05$ was considered as significant.

\section{RESULTS}

\section{Household consumption patterns of indigenous leafy vegetables}

Households reported to consume different types of indigenous leafy vegetables. Table 1 shows a summary of consumption patterns of indigenous African leafy vegetables at the time of the survey and others usually consumed.

Analysis of variance (ANOVA) showed no significant group differences ( $p>0.05)$ in mean monthly consumption of indigenous African leafy vegetables between urban and peri-urban residents. Results from the 24-hour recall and 7-day food frequency showed that only a few varieties of the indigenous vegetables were consumed at the time of the survey; and where they were consumed, they were consumed as relish accompanying staples such as ugali (maize meal), rice, maize and legumes or chapatti. The following indigenous vegetables were consumed during lunch and dinner; cowpea leaves (Kunde) (4.1\%), Jute (mrenda)(2.8\%), pumpkin leaves (Seveve, malenge leaves) (2\%), Amaranthus (Terere) (5.4\%), Bacella alba (Nderema) (2\%), spider plant (Saget, saga), black night shade (Managu, osuga) (2\%), Crotolaria (Mitoo) (3.9\%). Botanical names were obtained from (8). However as indicated in Table 1 a wide variety of indigenous vegetables were consumed at other times, once a month or rarely. About half of those who consumed these vegetables also reported that the vegetables were bought and not adequate. 


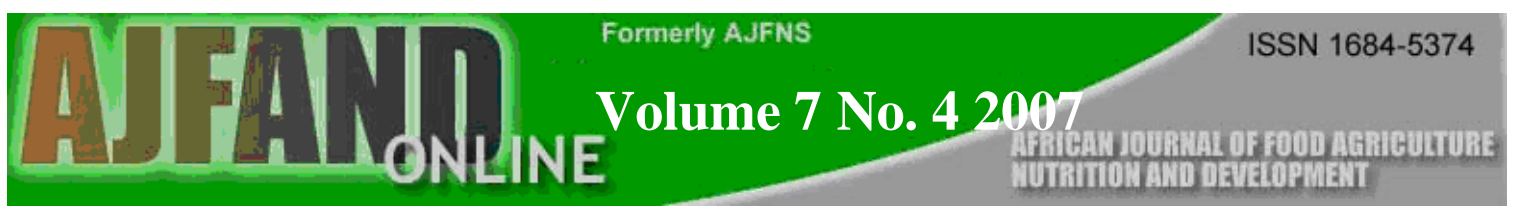

\section{Food Consumption Patterns Among Children 12-36 Months}

Results from the 24-hour recall showed that only a few children (23.2\%) consumed traditional plant vegetables. Consumption of leafy vegetables for lunch was as follows: cowpea leaves, pumpkin leaves, and nightshade with $7.8 \%, 7.6 \%$ and $1.3 \%$, respectively while pumpkin leaves were the most consumed for dinner at $15.3 \%$ followed by nightshade and amaranth at $2.5 \%$ and $0.6 \%$, respectively. Most of the children were consuming vegetables from the family pot.

\section{Factors Influencing Consumption of traditional foods}

Ethnicity was found to strongly influence choice and consumption of these vegetables. There was a significant difference $(p<0.05)$ in type and consumption of these vegetables between households with members originating from different tribes and those households with members originating from the same tribe (Table 2).

While $41.3 \%$ of the respondents indicated that they did not have problems in choice, preparation and consumption of foods, $7.5 \%$ of them reported that the foods were expensive. Further, $21.1 \%$, of the respondents reported that they lacked time to shop and prepare the indigenous leafy vegetables, while $1.1 \%$ indicated lacking knowledge on how to prepare them.

Results from the Focus Group Discussions (FGD) and observation guides indicated that traditional foods were readily available in urban and peri-urban Nairobi. The availability of traditional foods varied from estate to estate with Eastlands registering high accessibility to traditional foods. These foods were mainly sold in Kiosks, open markets and supermarkets. Most of these vegetables sold in open markets appeared fresh but were sold from poor environmental conditions. At times because of poor handling their qualities were perceived to be poor, an issue that discouraged many potential buyers from consuming these products. The most commonly sold traditional leafy vegetables in Nairobi were Jute (mrenda), crotalaria (mito), solanum (osuga/managu), spider plant (saget), amaranth, pumpkin leaves, and African kale. The survey was conducted during the hot months (February/March) and therefore most of vegetables were not available in large quantities.

The survey also sought to find out the methods used for preparation and cooking of the leafy vegetables. While most traditional leafy vegetables are nutritious if well cooked, findings from this survey indicated that respondents used preparation and cooking procedures, which could lead to a decrease of the nutritive value of cooked food. Some of the procedures used in preparing leafy vegetables, that need to be discouraged are described below: 


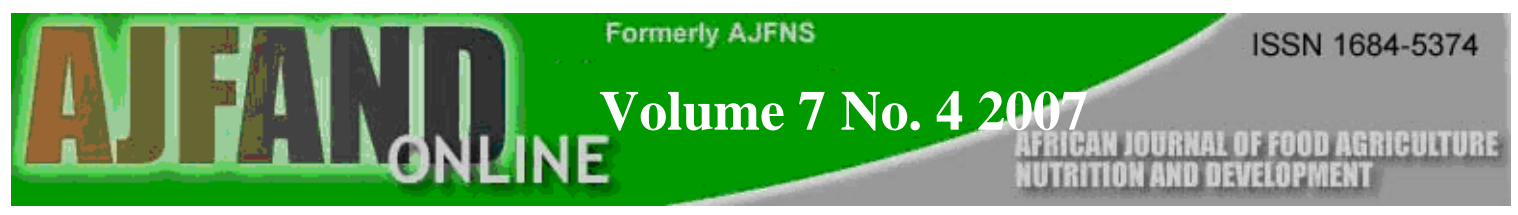

\section{(a) Chopping before washing}

Nearly half of the respondents $(43.1 \%)$ reported chopping their vegetables before washing. It is noted that water-soluble vitamins namely vitamin B complex and $C$ are lost during the washing stage if the vegetables are chopped before they are washed. Actually the colour of the washing water is green indicating presence of the nutrients. Some respondents repeated washing which further led to further loss of the water-soluble vitamins. However, a few households $(11.9 \%)$ reported to cook some of their vegetables whole such as, Mrenda, cowpea leaves, black nightshade and amaranths. This is encouraged since nutrients are not lost due to chopping.

\section{(b) Repeated boiling}

Many respondents $(79.1 \%)$ reported boiling the vegetables for a long time before frying. The boiling water, which could be containing nutrients, was also discarded. High temperatures such as those for boiling and cooking vegetables for more than 40 minutes as in the case of boiling and then frying also destroys vitamin $\mathrm{C}$ which is the most unstable vitamin.

\section{(c) Addition of sodium bicarbonate (magadi)}

Over three quarters of the respondents (77.1\%) reported adding sodium bicarbonate to vegetables especially cowpeas leaves during boiling. While sodium bicarbonate helps the vegetables tenderize and retain their bright green colour, vitamin $B$ complex namely vitamin $B_{1}, B_{2}$ and niacin are lost. This could thus indicate that most of the vegetables consumed might have lost these particular nutrients.

Other factors influencing the choice and consumption of indigenous vegetables included: occupation, sex, income and education levels. Occupation was found to influence choice and consumption of indigenous vegetables. There was a significant difference $(P<0.05)$ between consumption of indigenous vegetables and occupation with more casual labourers and/or non-employed respondents $(79 \%)$ than those in full time employment and business $(21 \%)$ consuming indigenous vegetables (Table 4). This was brought forth depending on the time one has for buying, preparing and cooking indigenous vegetables. There was no significant difference $(p>0.05)$ between men and women with regard to perceptions on consumption of indigenous vegetables. However, men were reported to have less preference for vegetables consumption compared to women. The survey also showed no direct relationship between households incomes except for cowpeas leaves with significantly $(P<0.05)$ more households with total household income of less than Ksh. 3000 consuming these vegetables

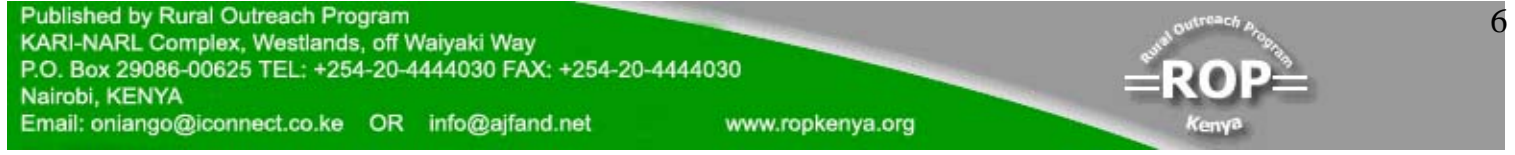




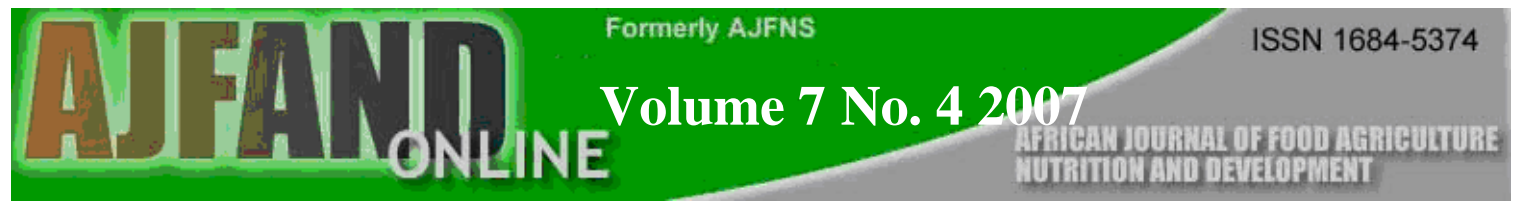

(Table 4). There were also no relationships between education and consumption of indigenous vegetables except for Spider plant (Saget) and pumpkin leaves with significantly more respondents with informal education and secondary education consuming these foods $(P<0.05)$, respectively.

\section{Medicinal Value of Indigenous Vegetables}

Generally, the respondents reported that the indigenous vegetables they consumed had a medicinal value attached to it. Some vegetables were reported to cure more than one illness. A wide range of illnesses was cited as being treated and/or managed by consumption of leafy vegetables. Presented in Table 4 are results on what respondents felt about the medicinal roles of indigenous leafy vegetables. However, there is need for further investigations to establish the basis of these perceptions.

The most common illnesses cited were malaria, diarrhea, anemia, colds and coughs, skin infections, malnutrition, HIV/AIDS, diabetes and high blood pressure among others. In addition to determining the medicinal value attached to indigenous vegetables by respondents, the survey also sought other values attached to these vegetables. The most common values attached were that the vegetables were: satisfying, a delicacy, appetite booster, and able to make one live long. Other values included improved blood flow, able to cleanse blood and so on (Table 5).

\section{DISCUSSION}

\section{Food consumption Patterns}

Recently there is a trend in the production and consumption of indigenous leafy vegetables as these have been found to be both nutritive and therapeutic. Indigenous leafy vegetables play a significant role in the nutrition and health status of the under privileged in both urban and rural settings [9]. Findings from the survey showed that ethnicity, occupation, sex, income and education levels are among some of the major factors affecting consumption and utilization of these vegetables. In a similar study, Maxwell and Frankenberger also found accessibility to also be a limiting factor [10].

Overall, consumption of indigenous leafy vegetables was low (34\%). These findings concur with those of Waudo et al. who reported low intakes of traditional vegetables by women and children in the wetlands of Lake Victoria region [11]. Consumption and utilization of indigenous leafy vegetables was highest when the vegetables were in season and prices were lower. Familiarity among adults with these vegetables accounted for their popularity in consumption and utilization. 


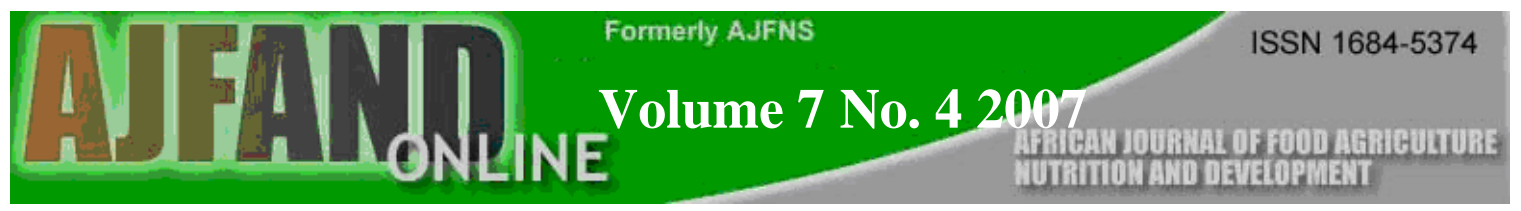

\section{Medicinal Value}

The diversity of indigenous plants and wild plants available in most tropical countries, in addition to providing essential nutrients, presumably offer broad benefits to health [12]. Studies have further shown that countries that retain indigenous vegetable diets and had high consumption of these vegetables are much less likely to be affected by cardiovascular diseases, diabetes and other adverse consequences of the nutrition in transition [6]. These findings concur with those of Johns and Musinguzi et al; , which found out that there was a potential relationship of indigenous vegetables and the ability to treat diabetes, gout, hyperlipidemia, gastro-intestinal tract infections, protozoan parasites, amongst others in Kenya and Tanzania [5, 13]. Olembo et al. also states that traditional vegetables have medicinal properties for the management of HIV/AIDS, stomach-related ailments and other diseases [14]. This is encouraging for intervention geared towards motivating individuals to increase the consumption and utilization of indigenous leafy vegetables. There is need for further investigation to establish the basis of the above-mentioned perceptions.

\section{CONCLUSION}

It is evident from these findings that only a small proportion (34\%) of the people living in urban and peri-urban Nairobi consume indigenous leafy vegetables. Consumption was based on ethnicity among other factors. The most consumed indigenous leafy vegetables by children were pumpkin leaves and cowpea leaves. Children were consuming the indigenous leafy vegetables from the family pot. The major constraint to consumption and utilization of indigenous leafy vegetables were the cost, lack of time and lack of knowledge in food preparation and cooking. Generally indigenous leafy vegetables were liked because they were nutritious and had a medicinal value attached. The respondents indicated a willingness to consume indigenous leafy vegetables if they were sensitized about their value and shown how to prepare them. This poses a challenge to relevant stakeholders to promote production, utilization (preparation and processing) and commercialization of indigenous leafy vegetables.

\section{ACKNOWLEDGEMENTS}

The Traditional Food Consumption and Utilization survey is a product of a combined effort of a team of nutritionists and postgraduate students from the department of Food, Nutrition and Dietetics, Kenyatta University, IPGRI staff, and Central Bureau of Statistics (CBS) personnel. We appreciate the contribution of Kenyatta University administration in facilitating the research process. The researchers gratefully acknowledge financial, logistic and advisory support from

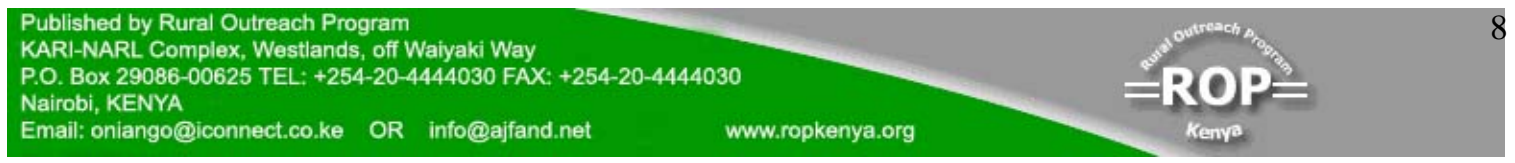




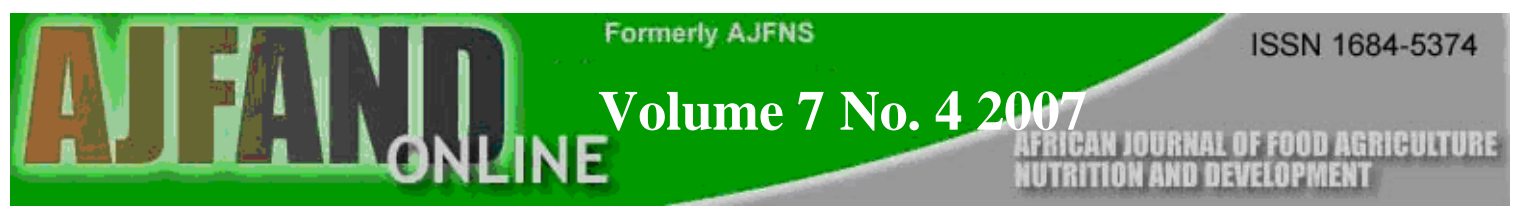

IPGRI Kenya office. We also acknowledge the Nairobi city administration and residents for their invaluable logistics support and willingness to respond to research instruments. 


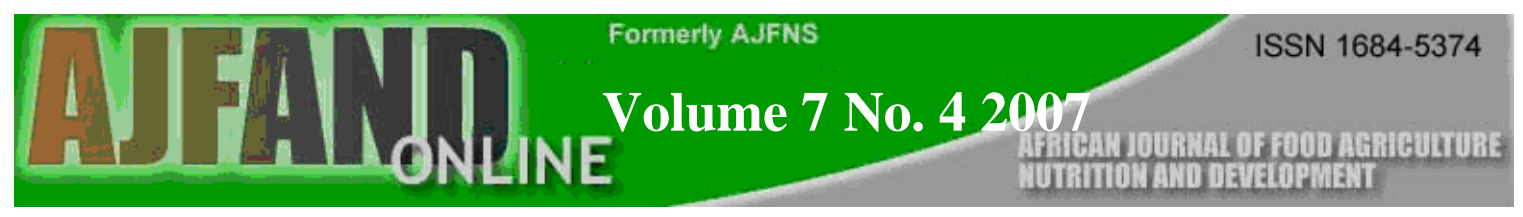

Table 1: Distribution of indigenous vegetables consumed by frequency and source

\begin{tabular}{|c|c|c|c|c|c|c|c|c|}
\hline \multirow[t]{2}{*}{ English name } & \multirow{2}{*}{$\begin{array}{l}\text { Consu } \\
\text { med } \\
\%\end{array}$} & \multicolumn{4}{|c|}{${ }^{\star}$ Frequency \% } & \multicolumn{3}{|c|}{ *Sources \% } \\
\hline & & 1 & 2 & 3 & 4 & $\begin{array}{l}\text { Own } \\
\text { produce }\end{array}$ & Bought & Donation \\
\hline Ethiopian/African Kale & 0.1 & $\begin{array}{l}0 . \\
1\end{array}$ & 0 & 0 & 0 & 0 & 0.1 & 0 \\
\hline Crotalaria sp/mitoo & 2.4 & $\begin{array}{l}0 . \\
3\end{array}$ & 0.9 & $\begin{array}{l}0 . \\
6\end{array}$ & $\begin{array}{l}0 . \\
6\end{array}$ & 0 & 2.4 & 0 \\
\hline Cow peas leaves & 8.2 & $\begin{array}{l}0 . \\
5\end{array}$ & 1.2 & $\begin{array}{l}6 . \\
5\end{array}$ & 0 & 0.1 & 8.0 & 0.5 \\
\hline Stinging nettles & 0.6 & 0 & 0 & $\begin{array}{l}0 . \\
6\end{array}$ & 0 & 0 & 0.6 & 0 \\
\hline Amaranths & 8.1 & $\begin{array}{l}0 . \\
4\end{array}$ & 0.6 & $\begin{array}{l}4 . \\
9\end{array}$ & $\begin{array}{l}2 . \\
2\end{array}$ & 0.3 & 7.6 & 0.2 \\
\hline Spider plant (Saget) & 4.3 & $\begin{array}{l}0 . \\
4\end{array}$ & 0.4 & $\begin{array}{l}0 . \\
8\end{array}$ & $\begin{array}{l}2 . \\
7\end{array}$ & 0.3 & 4.0 & 0 \\
\hline Pumpkin Leaves & 4.2 & $\begin{array}{l}0 . \\
1\end{array}$ & 0.3 & $\begin{array}{l}1 . \\
3\end{array}$ & $\begin{array}{l}1 . \\
5\end{array}$ & 0.6 & 3.4 & 0.1 \\
\hline Night shade & 5.4 & $\begin{array}{l}0 . \\
3\end{array}$ & 0.8 & $\begin{array}{l}0 . \\
9\end{array}$ & $\begin{array}{l}3 . \\
4\end{array}$ & 0.8 & 4.6 & 0 \\
\hline Jute (mrenda) & 3.4 & $\begin{array}{l}0 . \\
4\end{array}$ & 1.3 & $\begin{array}{l}1 . \\
1 .\end{array}$ & $\begin{array}{l}0 . \\
6\end{array}$ & 0 & 3.4 & 0 \\
\hline Arrowroot leaves & 1.1 & $\begin{array}{l}0 . \\
4\end{array}$ & 0.5 & $\begin{array}{l}0 . \\
1\end{array}$ & $\begin{array}{l}0 . \\
1\end{array}$ & 0 & 0.9 & 0.2 \\
\hline Comfrey & 0.6 & 0 & 0.1 & $\begin{array}{l}0 . \\
4\end{array}$ & $\begin{array}{l}0 . \\
1\end{array}$ & 0 & 0.6 & 0 \\
\hline Bean leaves & 0.4 & 0 & 0.2 & $\begin{array}{l}0 . \\
1\end{array}$ & $\begin{array}{l}0 . \\
1\end{array}$ & 0 & 0.4 & 0 \\
\hline $\begin{array}{l}\text { Nderema (Bacella } \\
\text { alba) }\end{array}$ & 0.2 & 0 & 0.1 & $\begin{array}{l}0 . \\
1\end{array}$ & $\begin{array}{l}0 . \\
0\end{array}$ & 0 & 0.2 & 0 \\
\hline Sweet potato leaves & 0.1 & $\begin{array}{l}0 . \\
1\end{array}$ & 0 & 0 & 0 & 0 & 0.1 & 0 \\
\hline
\end{tabular}

${ }^{*}$ Frequency codes: $1=2$ times a week $2=$ once a week $3=$ Once a month 4=rarely 


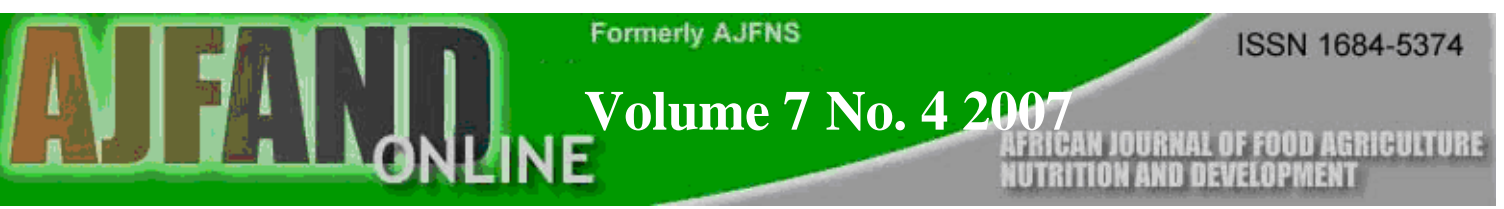

Table 2: Consumption of indigenous leafy vegetables by ethnicity

\begin{tabular}{|c|c|c|c|c|c|c|c|c|c|}
\hline $\begin{array}{l}\text { Indigenous } \\
\text { vegetables }\end{array}$ & $\begin{array}{l}\text { Embu } \\
(0.9 \% \\
\end{array}$ & $\begin{array}{l}\text { Meru } \\
\text { (2.3\% } \\
\text { ) }\end{array}$ & $\begin{array}{l}\text { Kamba } \\
\text { (11.3\%) }\end{array}$ & $\begin{array}{l}\text { Kikuyu } \\
\text { (42.5\%) }\end{array}$ & $\begin{array}{l}\text { Kisii } \\
\text { (4.6\%) }\end{array}$ & $\begin{array}{l}\text { Luo } \\
\text { (13.3\%) }\end{array}$ & $\begin{array}{l}\text { Luyha } \\
\text { (17.6\%) }\end{array}$ & $\begin{array}{l}\text { *Other } \\
\text { s } \\
(3.4 \%)\end{array}$ & $\begin{array}{l}{ }^{* *} X^{2} \\
\text { Sign. }\end{array}$ \\
\hline $\begin{array}{l}\text { Crotalaria } \\
\text { sp/mitoo }\end{array}$ & & & & 0.4 & & $\overline{1.3}$ & 2.0 & & 0.01 \\
\hline Amaranth & 0.3 & 0.6 & 1.9 & 9.4 & 0.5 & 2.5 & 2.7 & & \\
\hline Cowpeas leaves & 0.4 & 0.5 & 3.7 & 7.7 & 1.4 & 5.6 & 10.0 & 0.3 & 0.02 \\
\hline $\begin{array}{ll}\begin{array}{l}\text { Spider } \\
\text { (Saget) }\end{array} & \text { plant } \\
\end{array}$ & & & & & 1.9 & 3.7 & 2.9 & 0.3 & 0.01 \\
\hline Pumpkin Leaves & & & 1.4 & 3.7 & & 0.3 & 0.9 & & \\
\hline Night shade & 0.6 & 1.9 & 1.4 & 10.0 & 3.7 & 2.9 & 3.4 & 0.6 & \\
\hline Jute (Mrenda) & & & & & 0.9 & 3.9 & 3.7 & & 0.03 \\
\hline
\end{tabular}

Note: Only consumption by more than 1 respondent $(0.1 \%)$ indicated.

Figures in parenthesis represent percentages of respondent's ethnic group.

${ }^{*}$ Chi-square tests. Significance at $p<0.05$

Table 3: Household food consumption of traditional foods and total monthly income

\begin{tabular}{|l|l|l|l|l|l|l|l|l|}
\hline \multirow{3}{*}{$\begin{array}{l}\text { Indigenous } \\
\text { Vegetables }\end{array}$} & \multicolumn{7}{|l|}{ Household Monthly Income Levels (Ksh.) } \\
\cline { 2 - 12 } & $3000 \&$ & $3001-$ & $5001-$ & $10001-$ & $20001-$ & $30001-$ & $40001 \&$ & $\mathrm{X}^{2}$ \\
& Below & 5000 & 10000 & 20000 & 30000 & 40000 & above & Sign \\
& $(30.6 \%)$ & $(21 \%)$ & $(25.7 \%)$ & $(8.2 \%)$ & $(5.3 \%)$ & $(1.3 \%)$ & $(8.0 \%)$ &. \\
\hline Crotalaria sp/mitoo & 1.0 & 1.1 & 1.1 & 0.3 & 0.1 & 0.1 & 0.4 & \\
\hline Amaranth & 5.2 & 4.0 & 4.3 & 1.9 & 1.3 & 0.4 & 1.6 & \\
\hline Cowpeas leaves & 8.0 & 7.1 & 8.0 & 3.3 & 1.9 & 0.3 & 2.3 & 0.03 \\
\hline spider plant(Saget) & 2.8 & 1.9 & 2.4 & 0.9 & 0.3 & 0.3 & 0.9 & \\
\hline Pumpkin Leaves & 2.8 & 1.1 & 1.0 & 1.3 & 0.5 & 0.3 & 0.9 & \\
\hline Night shade & 7.1 & 5.8 & 6.6 & 2.3 & 1.9 & 0.1 & 2.1 & \\
\hline Jute/mrenda & 2.1 & 1.5 & 3.3 & 0.6 & 0.4 & 0.1 & 0.6 & \\
\hline
\end{tabular}

$\mathrm{X}^{2-}$ Chi-square tests. Significance at $\mathrm{p}<0.05 \quad{ }^{\star}$ Figures represent percentages 


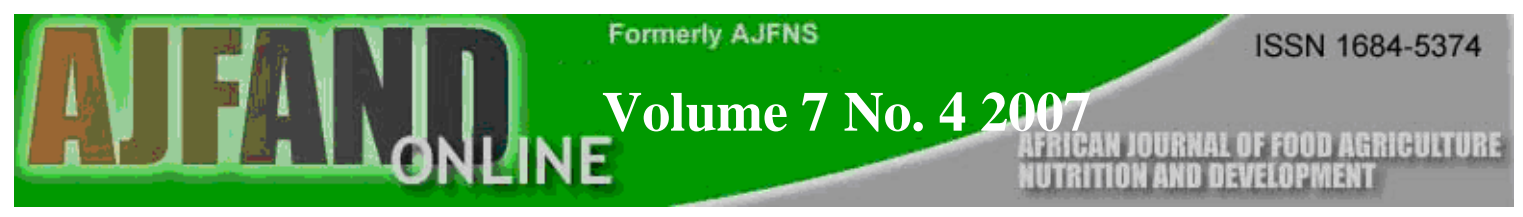

Table 4: The attached and medicinal value of indigenous leafy vegetables as reported by respondents

\begin{tabular}{|c|c|c|c|}
\hline $\begin{array}{l}\text { Indigenous } \\
\text { vegetable }\end{array}$ & Attached value & Medicinal value & $\% \mathrm{~N}=791$ \\
\hline $\begin{array}{l}\text { Mukimo (with } \\
\text { pumpkin leaves) }\end{array}$ & Delicacy & $\begin{array}{l}\text { treats diabetes, high } \\
\text { blood pressure, } \\
\text { backache }\end{array}$ & 6.2 \\
\hline Ethiopian Kale & Cleanses blood & - & 0.5 \\
\hline Pumpkin leaves & & Improves eye sight & 4.1 \\
\hline Garlic & $\begin{array}{l}\text { Boosts appetite, } \\
\text { revitalizes the body }\end{array}$ & $\begin{array}{l}\text { Colds and coughs, high } \\
\text { blood pressure, stomach } \\
\text { ache, cancer, Asthma, } \\
\text { TB }\end{array}$ & 5.8 \\
\hline Ginger & $\begin{array}{ll}\text { Nourishing } & \text { and } \\
\text { revitalizing } & \\
\end{array}$ & $\begin{array}{l}\text { Colds and coughs, high } \\
\text { blood pressure }\end{array}$ & 2.3 \\
\hline Stinging nettles & $\begin{array}{l}\text { Boosts appetite } \\
\text { Cleanses blood }\end{array}$ & $\begin{array}{l}\text { Anemia, fainting, colds } \\
\text { and coughs, backache }\end{array}$ & 1.3 \\
\hline Black night shade & $\begin{array}{lc}\text { Boosts } & \text { appetite, } \\
\text { general comfort, } \\
\text { cleanses blood }\end{array}$ & $\begin{array}{l}\text { Malaria, stomach ache, } \\
\text { colds and coughs, high } \\
\text { blood pressure, diabetes } \\
\text { chest pains }\end{array}$ & 10.0 \\
\hline $\begin{array}{l}\text { Crotalaria sp/mitoo } \\
\text { Mitoo/miroo }\end{array}$ & Cleanses blood & Stomach ache & 3.9 \\
\hline Cow peas leaves & Boosts appetite & Digestive problems & 3.9 \\
\hline Amaranth & Boosts appetite & $\begin{array}{l}\text { Malaria, colds and } \\
\text { coughs, AIDs, stomach } \\
\text { ache, diarrhea, skin } \\
\text { rashes, diabetes, back } \\
\text { ache }\end{array}$ & 2.3 \\
\hline Spider plant (saget) & Cleanses blood & Stomach ache & 6.9 \\
\hline Pumpkin leaves & Boosts appetite & $\begin{array}{l}\text { Malaria, typhoid, high } \\
\text { blood pressure, stomach } \\
\text { ache, oedema } \\
\text { constipation, general } \\
\text { health }\end{array}$ & 4.0 \\
\hline $\begin{array}{l}\text { Nderema (Bacellas } \\
\text { alba) }\end{array}$ & General good health & - & 0.5 \\
\hline $\begin{array}{l}\text { Jute }(\text { Mrenda) } \\
\text { (Bush okra) }\end{array}$ & Boosts appetite & Stomachache, anaemia & 7.7 \\
\hline
\end{tabular}




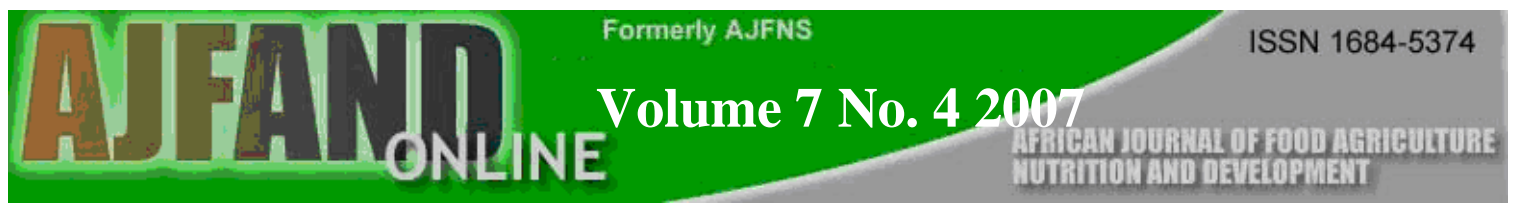

\begin{tabular}{|l|l|l|l|}
\hline $\begin{array}{l}\text { Muthunga or } \\
\text { mchunga }\end{array}$ & - & Backache & 0.6 \\
\hline $\begin{array}{l}\text { Arrow root leaves } \\
\text { (Matekyo) }\end{array}$ & Boosts appetite & Diarrhoea & 3.1 \\
\hline
\end{tabular}




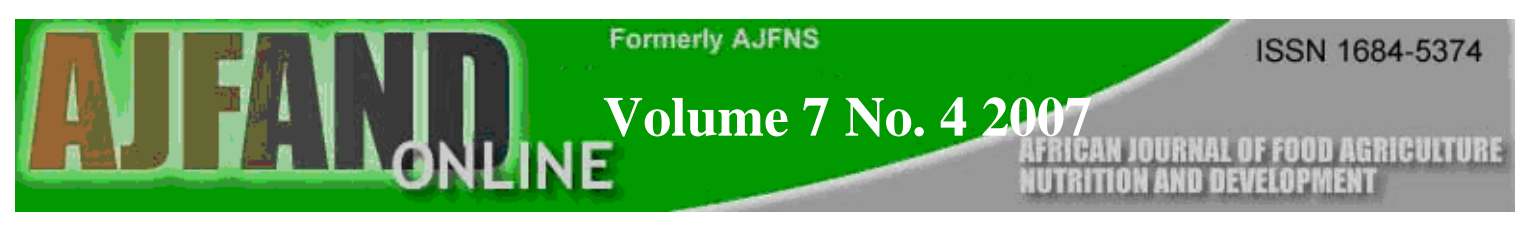

\section{REFERENCES}

1. IPGRI. Reducing hidden hunger and malnutrition through traditional foods. IPGRI newsletter for Sub-Saharan Africa. Nairobi, Kenya. 2006; 1-3.

2. Abukutsa-Onyango MO Unexploited potential of indigenous African indigenous vegetables in Western Kenya. Maseno Journal of Education, arts and Science 2003; 4:103-122.

3. Popkin BM, Horton $\mathbf{S}$ and $\mathbf{S}$ Kim The nutrition transition and prevention of diet-related diseases in Asia and the Pacific. Food Nutri Bulll. 22: Suplement 58. 2001

4. Schippers RR African indigenous vegetables. An overview of the cultivated species. Chatham, UK. Natural Resources Institute/ACP-EU Technical Centre for Agricultural and Rural Cooporation.2002.

5. Johns T Plant Bio-diversity and malnutrition: Simple solutions to complex problems: Theoretical Basis for the Development and Implementation of a Global Strategy Linking Plant Genetic Resource Conservation and Human Nutrition. African Journal of Food, Agriculture, Nutrition and Development. 2004; 3-3.

6. Johns $\mathbf{T}$ and $\mathbf{B}$ Sthapit Bio-cultural diversity in the sustainability of developing country food systems. Food and Nutrition Bulletin vol. 25 No. 2. 2004; 143-155.

7. IPGRI. Foods of the Nairobi people: A picture book of foods in Nairobi markets. IPGRI, Nairobi, Kenya. 2005.

8. Maundu PM, Ngugi GW and CH Kabuye Traditional Food plants of Kenya. KENRIK, National museums of Kenya. 1999: 270.

9. Gackowski J, Mbazo J, Mbah G and T Moulende African traditional leafy vegetables and the urban and peri-urban poor. Food policy 28.2003; 221-235.

10. Maxwell S and TR Frankenberger Household Food Security: Concepts, indicators, measurement - A Technical Review. Jointly sponsored by UNICEF and IFAD. 1992.

11. Waudo J, Tuitoek P, Msuya J, and J Kikafunda Food Consumption Patterns and Nutrient Intakes by women and Children under five in the wetlands of Lake Victoria basin. Research report for . VICRES. 2005. 
12. Onyango MA, Tushaboomwe-Kazoobz C, Onyango JM and SE Macha Improved Community Landuse for Sustainable Production and Utilization of African Indigenious Vegetables in the Lake Victoria Region. VICRES Report 2005.

13. Musinguzi E, Kikafunda $\mathbf{J}$ and $\mathbf{B T}$ Kiremire The status and level of utilization of indigenous food plants in Uganda: A case study of South West Uganda. Department of Food Science and Technology. Makerere University, Kampala Uganda.2000.

14. Olembo NK, Fedha SS and ES Ngaire Medical and Agricultural Plants of Ikolomani, Kakamega District, Kenya. 1995. 